\title{
The Rise and Decline of US Interest and Influence in Kyrgyzstan
}

\author{
Dr. Faisal Javaid \\ Assistant Professor \\ Department of International Relations \\ FUUAST, Karachi-Pakistan \\ faisal.javaid@fuuat.edu.pk \\ $\&$ \\ Dr. Suwaibah Qadri \\ Assistant Professor \\ Department of Political Science \\ University of Karachi \\ suwaibahq@gmail.com
}

\begin{abstract}
The rise of independent Central Asian states after the disintegration of the USSR has transformed the regional geostrategic environment. America quickly established diplomatic relations with the Kyrgyz Republic in 1991. Kyrgyzstan is not a wealthy state and it is facing several challenges such as ethnic issues, bad governance, narcotics, and foreign involvements. After the 9/11 events, the state got special attention for America due to its geographical position towards Afghanistan. Kyrgyzstan condemned these attacks and supported to anti-terrorist alliance. It offered military bases for operation in Afghanistan after the relation between America and Kyrgyzstan have strengthened. After the tulip revolution, both states' relationships were affected. This research examines the role of the United States in Kyrgyzstan. It also examines the political, economic, and security relations between the U.S. and Kyrgyzstan. This study evaluates the several challenges tackled by the United States.
\end{abstract}

Key Words: America, Kyrgyzstan, Central Asia, Political Relations, Economic Relations, Defense Relations

\section{Introduction}




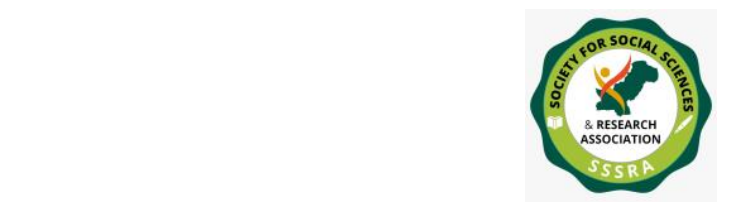

The Rise and Decline of US Interest ...

In the region of Central Asia, the country of Kyrgyzstan was not a big and wealthy that got independent in the year 1991 with the Soviet Union's divided and it was situated in the Central Asian hilly territory. The geographic position of Kyrgyzstan close to Afghanistan and along with China had generated this calm agrarian country an essential concern to the U.S. After the attacks of 9/11, the U.S required tactical places from which it could help the action of its armed forces within the Kyrgyzstan and Afghanistan to fit the bill. Over the precedent years, though, the relationships of the U.S with Kyrgyzstan had been surpassed by Afghanistan's anti-terrorism movement. Collaboration over armed forces and safety matters overcame numerous help plans connected to the pack of Kyrgyzstan to host a U.S airbase at the airport of Manas in the year 2001. U.S-Kyrgyzstan relationships were expected to more transform in the year 2014 as the number of troops of the U.S in Afghanistan was considerably decreased and the agreement for the airbase of Manas ends (Marat, 2013b, p.3).

The US opened the Transit Center at Manas in December 2001 after the 9/11 occurrence. Both Russia and China were unnerved and in later years allegedly offered enormous bounties if Kyrgyzstan shut the base. In 2006, the President of Kyrgyzstan requested further concessions to the understanding and in this year a US Air Force faculty official was hijacked (media later revealed inconsistencies in this record; the USAF reconfirmed a grabbing occurred in 2012). 2006 likewise saw the slaughtering of a Kyrgyz regular citizen using a blade by a US serviceman with a weapon. Nearby Kyrgyz opinion and media were insulted as the Kyrgyz district is tormented by wilderness, banditry, and pirating and the conveying or in any event, undermining with a blade is moderately basic in Kyrgyz road culture. For the Americans, faltering and crushed from the 9/11 fear-based oppressor attack on their biggest city, any persuasive passage by a regular citizen into an army installation can and is met with lethal power. The US military set the serviceman under managerial discipline and an undisclosed monetary repayment was made to the family.

As indicated by the 2012 U.S. Worldwide Leadership Report, 34\% of Kyrgyz individuals favor U.S. authority, with $43 \%$ objecting and $23 \%$ uncertain.

In July 2015, the Kyrgyzstan Ministry of Foreign Affairs stopped a two-sided collaboration settlement endorsed by the two nations in 1993, amid fights by the Kyrgyz unfamiliar service over the U.S. Branch of State's choice to grant the 2014 Human Rights Defender Award to Kyrgyz detainee Azimzhan Askarov, a 


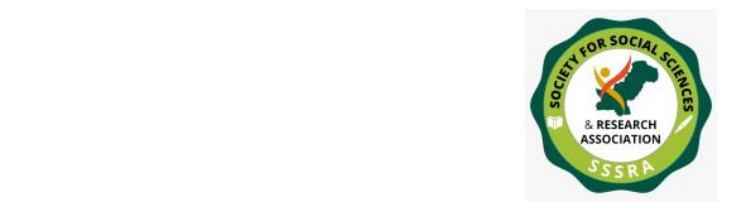

The Rise and Decline of US Interest ...

columnist and political dissident who was captured for his commitments in the 2010 South Kyrgyzstan ethnic clashes. The U.S. has since cautioned Kyrgyzstan of the retraction's ramifications in regards to the arrangement of philanthropic and security aid. Three months after the fact, U.S. Secretary of State John Kerry visited Kyrgyzstan with an end goal to ease reciprocal ties.

After the October 2011 official political decision in Kyrgyzstan, President Obama advertised congrats to individuals and administration of the country for holding a "majority rule and serene" political race and for taking "a significant and gallant advance on the way of the majority rules system

What's more, demonstrate their obligation to an organized and open change of force." He too vowed that "individuals of Kyrgyzstan will have an accomplice in the United States as they attempt the difficult work of expanding upon the majority rule gains [since the April 2010 coup] and understanding a popularity based, prosperous and only future for all Kyrgyz citizens."42 In a public statement in December 2011 commending 20 years of reciprocal relations between the United States and Kyrgyzstan, U.S. Representative to Kyrgyzstan Pamela Spratlen expressed that the United States is "completely dedicated to helping out the public authority and individuals of the Kyrgyz Republic to meet the most earnest advancement needs all through the country. As the business climate improves, we desire to extend exchange and speculation ties. We additionally stand side by side on the world stage as authentic accomplices with shared interests in looking for a steady, secure region. In a declaration to Congress in July 2012, Assistant Secretary of State Robert Blake expressed that uphold for democratization in Kyrgyzstan was a "foundation" of U.S. strategy in Central Asia, since the nation drives the district in democratization. Help endeavors have incorporated the preparation of electing laborers, uphold for ethnic compromise, legal changes, finishing prisoner mishandles, and considering the culprits of such maltreatment responsible. $\mathrm{He}$ additionally lauded Kyrgyzstan's support as some portion of the Northern Distribution Network for the travel of U.S. furthermore, NATO gear to and from Afghanistan, and the nation's facilitating of the U.S. Manas Transit Center for military air trips all through Afghanistan.

There had been a concern of the U.S to help Kyrgyzstan to improve its independence and territorial veracity, strengthen financial reform and progress, fortify human rights, avoid arms propagation and further efficiently battle international violence and trafficking in narcotics and persons. Unusual 


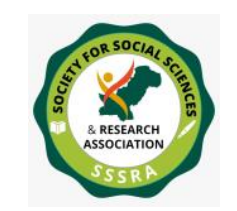

Pak. Journal of Int'L Affairs, Vol 4, Issue 1 (2021)

The Rise and Decline of US Interest ...

concentration long had been cited on strengthening civilization and democratic process in what had emerged to be the mainly amenable but at rest demanding social and political setting in the Central Asian region (Nichol, 2013). Since the year 1991, Kyrgyzstan had attained inspiring democracy-related benefits in contrast with its neighbors in this region. The meaning of Kyrgyzstan to the United States expanded after the September 11, 2001, psychological militant assaults on the United States. Kyrgyzstan offered to have U.S. powers at an airbase at the Manas worldwide air terminal outside of the capital, Bishkek, and it opened in December 2001. The U.S. military fixed and later overhauled the landing strip for flying refueling, transport and airdrop, clinical clearing, and backing for the U.S. also, alliance staff and load traveling in and out of Afghanistan. The Kyrgyz government took steps to shut down the airbase in mid-2009, yet recharged the rent on the airbase (renamed the Manas Transit Center) in June 2009 after the US consented to higher rent and different installments. President Almazbek Atambayev and the assembly have expressed that the basing understanding won't be recharged when it terminates in 2014. As of 2013, the Manas Transit Center reports that it has around 1,500 U.S. troops and U.S.workers for hire and an armada of KC-135 refueling big haulers and C-17 vehicle airplanes. Other than facilitating the Manas Transit Center, Kyrgyzstan additionally takes an interest as a component of the Northern Distribution Organization for the travel of military supplies to and from Afghanistan. It had been the single state to have accomplished viable and free parliamentary polls in the year 2010 and serenely shifted powers of the President in the year 2011. Major obstructions to the progress of Kyrgyzstan comprise aging infrastructure, corruption, a high ratio of joblessness, and widespread poverty. However, Kyrgyzstan gains benefits from a vigorous civilization and a comparatively liberated media division (U.S. Relations with Kyrgyzstan, 2013).

\section{Political Relations}

Along with the initiation of the breaking up of the Soviet Union, Kyrgyzstan declared its sovereignty on 31, August 1991. The U.S accepted sovereignty of Kyrgyzstan and diplomatic relationships were formed on 25, December 1991 owing to its supposedly democratic head, (Nichol, 1995, p.157), when George H.W. Bush, President of the U.S proclaimed the verdict in a speech to the country about the Soviet Union's finality (Office of the Historian, n.d.) Earlier, Kyrgyzstan had been an ingredient state of the U.S.S.R. The Embassy of the U.S situated in Bishkek was formed on the $1^{\text {st }}$ of February 1992 and an embassy of Kyrgyzstan was launched in Washington later that year (Buyers, 2003, p.167). 


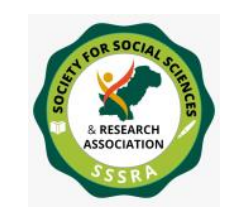

The Rise and Decline of US Interest ...

Their two-sided relationships break on over numerous accords and MOUs have bargained throughout the trips on diverse stages commonly beneficial affiliation between the Kyrgyzstan and U.S that could be served up as an instance of nearer collaboration between these two (Aidarkul and Omarov, 2003). With profound admiration for the qualitatively fresh lasting relationships that had been rising between them and that were dependent over the mutual objectives in confronting the global violence; expansion of safety, political and armed forces collaboration; collaboration in the disciplines of finance, industry, education, and science and technology et cetera. Between the duration of the year 1991 to the year 2010, the U.S used a collective $\$ 1.22$ billion on a variety of agendas in the country, to make Kyrgyzstan the third biggest per capita receiver of the aid of the U.S amongst the ex-Soviet states. The U.S also favored the accession of Kyrgyzstan to the World Trade Organization in the year 1998 (Marat, 2013b, p.3).

The 9/11 incident unlocked a new chapter in the relationships between the U.S and Kyrgyzstan. The counter-terrorist Action Lasting Autonomy carried U.S citizens to the Central Asian region and its components were positioned in Kyrgyzstan with the unusual accords between them. President of the Kyrgyz Republic, Askar Akaev visited the United States from September 19-24, 2002 on the invitation of President Bush. This visit contributed significantly to promote two-sided relationships. This was an essential occasion that formed a mutual declaration planned to assist them to attain mutual objectives: regional safety and steadiness sustained democracy-related progress in Kyrgyzstan and the support of the U.S of its financial progress. The major outcome of the summit was to consolidate the fresh arrangement of twosided relationships that had been shaped post 9/11 attacks (Congressional Record, Vol-148, 2002).

The foreign policy of Kyrgyzstan had been managed by two thoughts, first that the state was too little and too deprived to be financially practicable with no substantial exterior help, and second that it stands in an unstable place of the world, susceptible to numerous horrible possibilities. The United States had become an influential nation in Central Asia, including in Kyrgyzstan, in the post-Soviet era. Following a regional trend, the Kyrgyz had established ties with Washington while maintaining relationships with Moscow. These types of bindings assist Bishkek poise Russia by keeping away from serious dependence on it and therefore protecting the sovereignty of Kyrgyzstan (Peimani, 2009, p.147). Because the relationship offered by the United States was so limited, the Kyrgyz focused their attention on 


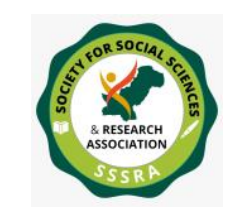

The Rise and Decline of US Interest ...

achieving geopolitical balance, reaching out to China and Russia, rather than putting all their eggs in a U.S. basket (Olcott, 2010, p.181).

The US government provided civilization support non-deadly armed forces help and help to support political and financial reforms. It also had assisted the State of Kyrgyzstan's demands for backing from worldwide associations. The U.S supported the State of Kyrgyzstan's assent to the WTO in December 1998. U.S support aids the State of Kyrgyzstan to implement essential educational, health side, and financial reforms and backs financial expansion and divergence resolution in the Fergana Valley (USA International Business Publications, 2012, p.25). Kyrgyzstan state also was a contributor to the North Atlantic Treaty Organization's Corporation for Peace plan and linked with it in the year 1994 (Blank, 1998).

Relationships with the U.S were damaged early in the year 2006 when Kyrgyzstan made a demand for a hundredfold augment in U.S compensations for utilization of the airbase of Manas. A new rental accord, in July 2006, in favor of Kyrgyzstan, calmed anxieties for the time being (Cooley, 2006, p.1-4). U.S relationships with the state of Kyrgyzstan, thus, had for all time been embedded in the perspective of the region. Such as, Bishkek was approached by Washington concerning becoming a host of a U.S air force base owing to its suitable position for the U.S armed forces movement in Afghanistan post 9/11 attacks.

Akayev ran unobstructed and was nominated president of the latest sovereign state in Oct. 1991. In February 2003, a contentious referendum enlarged the authorities of Akayev and in June he was given exemption from trial by parliament for a lifetime. False parliamentary polls; that were organized at the end of Feb. 2005; flashed revolutions in the provinces of the south and these gradually collected energy as diverse opponent groups and civil NGOs combined on a platform against Akayev. On 20 March, uprisings exploded in the towns south of Osh and Jalalabad, and then on 23 March, protests occurred in Bishkek. The safety facilities could not determinedly dig these masses and the regime of Akayev deteriorated the very next day when masses doing protest blizzard the White House of President. On 4 April 2005, Akayev ran away to Russia and officially gave the resignation from the Presidency (Cooley, 2008, p78).

Opposition leader Kurmanbek Bakiyev did the job as provisional prime minister and president until the polls of 10 July in which he succeeded as the President. On 23 July 2009, President Bakiyev was elected once again, even though there were 


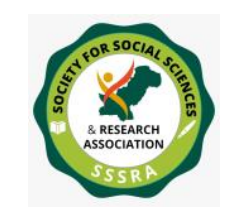

The Rise and Decline of US Interest ...

numerous indiscretions highlighted by the Organization for Security and Cooperation in Europe. On 7 April 2010, the government was deposed by famous protests focused on the cruelty and dishonesty of government. A provisional government was formed which was led by ex-minister of foreign affairs $\mathrm{Mr}$. RozaOtunbayeva. Despite the political crises of 2010, Kyrgyzstan held a constitutional referendum and successful and competitive parliamentary and presidential elections, all of which replicated the determination of the public. The peaceful and democratic transition of Presidency on 1 December 2011 patents the first such shifting of authorities in the history of the country (Kyrgyzstan European Forum for Democracy and Solidarity, 2014).

The U.S. plans to assist the democracy had made a significant input to the democracy-related progress of Kyrgyzstan. Adequate sources had been expended to promote the independent media, civic education, polls that were fair and free, and political contribution. Numerous agencies of the U.S government head amongst them the US-AID, in addition to NGOs like the Freedom House, Soros Foundation, and National Endowment for Democracy had served to fortify the country's democracy-related processes. During the elections, the support was given by the U.S for the administration of elections, guidance for political groups, and help with broadcasted debates of candidates, assistance for civil society commitment, and healthy election observing endeavors (Kyrgyz Republic: Fact Sheet, 2012). The U.S. budgeted foreign aid to Kyrgyzstan from 1992 to 2010 was $\$ 1.22$ billion (Nichol, 2013). Their major parts of aid were legislative strengthening, free media and independent political parties, civil society, and smoothing the progress of cultural reunion and judicial reform.

Kyrgyzstan had a lively NGO society and numerous free mass media channels. Even if these voices were for the time being repressed by president Bakiyev, but yet they came back with fresh power after his upheaval in April 2010. NGOs and media channels contributed significantly to working the spirited parliamentary polls in October 2010 and presidential polls after a year.

After the 2005 uprising, President Bush stated that they came collectively at a grand instant in times past when independence is on the march around this globe. In the previous year and a half belief regarding this they had observed Orange Revolution in Ukraine, Rose Revolution in Georgia, Tulip Revolution in Kyrgyzstan, Iraq's Purple Revolution, Lebanon's Cedar Revolution, and these were reckoned as only the starts (U S Government. Public Papers of the Presidents, 2009). Throughout the 


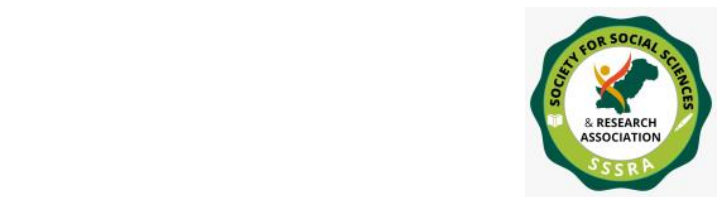

Pak. Journal of Int'L Affairs, Vol 4, Issue 1 (2021)

The Rise and Decline of US Interest ...

Central Asian region, hope was to rise at the outlook of change and modification will arrive.

Following Kyrgyzstan's polls to elect the President, in October 2011, President Mr. Obama congratulated the citizens and administration of the country because they succeeded to held democratic and calm polls and to take a significant and brave stride on the trail of democracy and show their pledges to an arranged and independent power transition (Statement by President Obama on the Presidential Elections in Kyrgyzstan, 2011). He also vowed that the citizens of Kyrgyzstan would become a collaborator in the U.S as they commence the hard work to build the democratic advantages since the April 2010 overthrow and understanding a democratic, wealthy, and just prospect for the citizens of Kyrgyzstan.

In July 2012, Mr. Robert Blake, U.S Assistant Secretary declared that assistance for Kyrgyzstan's democratization was a foundation stone of the plan of the U.S. in the region of Central Asia since the state guides this region in democratization (Blake, 2013). He also stated in January 2013 that the democracy of Kyrgyzstan is an example for this region while supporting that the country builds development to improve inter-cultural relationships in Kyrgyzstan's southern zone (Todd, 2011).

The leaders of Central Asian states learned a lesson from the Colored Revolutions, which were Rose in Georgia in the year 2003, Orange in Ukraine in the year 2004, and Tulip in Kyrgyzstan in the year 2005, was that the U.S was not a collaborator on whom they had be capable to depend as they tackle the largest political test since they rose to power progression (Roy, 2010). American endorsement of Colored revolutions and heavy investment in the endorsement of democratic progress comprised a sign to elites of Central Asia that Washington was not a leader of safety, but a mediator of transformation. They were probable to observe its fairness with the citizens of Central Asia, not its heads.

The growing U.S. pressure in Kyrgyzstan although had originated a response from the Kremlin, articulated in the shape of financial sanctions, not in favor of Bishkek and support of Moscow of unhelpful propaganda utilized by the opposition groups of Kyrgyzstan in opposition to the authorities. An augmented U.S armed forces existence exclusive of support by Russia could finally harm the country's local condition, but be optimistic via an increasing economic and technical pledge for political modifications and financial progress (Akimbekov, 2012, p.5.). 


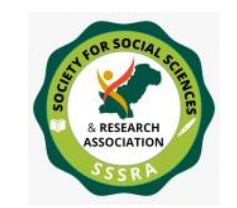

The Rise and Decline of US Interest ...

The Kyrgyz clashes contributed to the already week Central Asian region and poisoned the area for generations. It was hoped that this region could not be like Yugoslavia - which witnessed ethnic clashes in the past. Russian also had to worry as several people had lost their lives in Kyrgyz and Uzbeks clashes of Osh and Jalalabad. Similarly, the Mayor of Osh had opposed the deployment of a foreign force. In those areas, slogans like "No Kosovo" and "No Yugoslavia in Kyrgyzstan" could be heard everywhere in the country.

In the light of a report issued by the State Department of U.S, (the Kyrgyz Republic Human Rights Report, 2013) the main dilemmas related to human rights comprised constant cultural worries in the Southern zone; torment and violence by officers of law enforcement; deprived prison situations; random detain and imprisonment; shortage of independence of the judiciary; stress on nongovernmental organizations (NGOs) and leader from the opposition parties, together with government persecution; an augment in stress on sovereign media, as well as attacks on employees and destruction of assets; government persecution and imprisonment of congregation directors; constraints on spiritual liberty authorities' collapse to defend immigrants sufficiently; invasive corruption; favoritism in opposition to women, trafficking in persons, disabled persons, Child labor, homosexuals and racial minorities.

An NGO named Freedom House was sustained to categorize Kyrgyzstan as partially independent in the year 2012 in the field of social freedom and political rights (Puddington, 2013, p.16). USAID worked in close partnership on several projects with Kyrgyzstan on Media Support Initiative, Kyrgyzstan's Judicial Strengthening Program and Partners in Human Rights, etc. USAID had given substantial upkeep to the prosperous mass media region to support safeguard that people had admission to trustworthy and various bases of data.

USAID assisted the judicial system by rising its sovereignty, efficiency and reliability; amplification Kyrgyzstan's rule of law; corruption lessening, giving support to the freedom of judiciary, judiciary related personnel system improving and interior judicial administration; reinstating judicial veracity by mounting unrestricted access to information related with the judiciary and to manage it. Notwithstanding this guide, the Millennium Challenge Corporation (MCC) - made in 2004 to give U.S. help to nations with promising improvement records - reported in late 2005 that Kyrgyzstan was qualified to apply for help as a country on the "edge" of meeting the rules for full-scale improvement help. In March 2008, the 


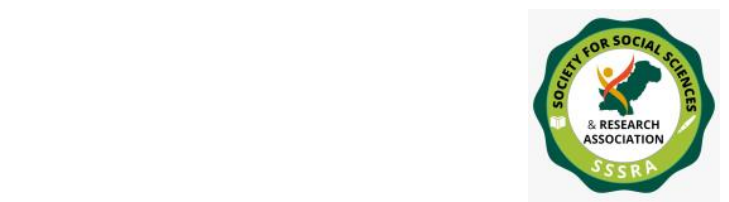

The Rise and Decline of US Interest ...

MCC consented to an arrangement with Kyrgyzstan to give $\$ 16$ million over the following two years to help it battle defilement and reinforce legal change. The program was finished in FY2010. MCC has not considered Kyrgyzstan qualified for an MCC reduced, including due to its presentation on the guideline of law and hostile to defilement markers utilized by MCC to assess qualification, however, the Kyrgyz government trusts that upgrades in these regions will make it qualified later on.

\section{Economic Relations}

U.S. economic relations with Kyrgyzstan were limited because of Kyrgyzstan's lack of major oil and gas deposits the main spotlight of United States economic interest in the Central Asian region. Hence, the importance Washington ascribes to Kyrgyzstan was mainly political, a counterbalance to Russia, although small amounts of American economic aid to Bishkek were also important to Kyrgyzstan, being, along with Tajikistan, the poorest Central Asian nation. The U.S was completely dedicated to collaborating with Kyrgyzstan; it hoped to enlarge business and bindings related to the investment. The U.S. is also placed side by side on the globe point as real colleagues with joint concerns in looking for a steady and protected region. (Spratlen, 2011)

Economic relationships between the U.S and Kyrgyzstan were incomplete and disordered. U.S imports to Kyrgyzstan were far less than the exports to it. Its total trade was $109.8 \$$ million in 2013, in which exports and imports were respectively $\$ 106.3$ million and only \$3.5 million. (Trade in Goods with Kyrgyzstan. 2020). The bilateral trade between the two countries had tripled over the last decade. Exporting products of Kyrgyzstan to the U.S include mercury, antimony, chemical products, and rare earth metals. It imports medicine, medical tools, grain, paper products, vegetable oil, apparatus, rice, meat, and agricultural apparatus from the U.S.

The current trade, economic, and investment cooperation between Kyrgyzstan and the USA was rather modest. The US accounts for only $2.8 \%$ of Kyrgyzstan's foreign trade. Over the past three years, the economy of Kyrgyzstan had received only $\$ 5.52$ million of direct investment from the U.S. (Savina, 2014) Its straight investment in Kyrgyzstan was concerted in the sectors of hotels and telecommunication. Kyrgyzstan had approved a two-sided investment accord with the U.S. The accord on twice excise taxation that was approved by the Soviet Union and U.S stayed same in effect among Kyrgyzstan and U.S. Kyrgyzstan likewise 


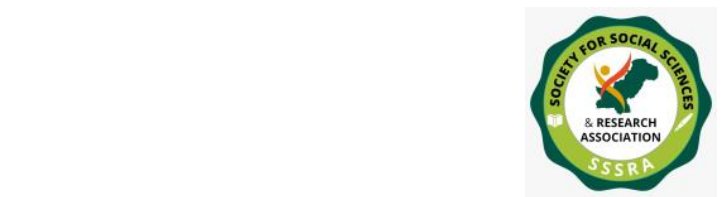

Pak. Journal of Int'L Affairs, Vol 4, Issue 1 (2021)

The Rise and Decline of US Interest ...

approved an investment and business structure accord by the U.S and further countries of Central Asia setting up a regional meeting to talk about the courses to develop investment atmospheres and enlarge business within the region of Central Asia.

After the closure of the Manas transit center, the biggest impact on Kyrgyzstan's economy its cost was 60 million dollars per year; Kyrgyzstan's GDP was only USD 6.47 billion. Manas contributed USD 145 million annually to the Kyrgyz economy. Kyrgyzstan will feel the full effects of the closure in 2015, where the revenue collection gap was USD 120 million. Russia and other regional partners may not be able to compensate for the economic damage and the loss of jobs among Kyrgyz nationals. Existing political instability will make the recovery more difficult to achieve (Brletich, 2013). America established Annual Bilateral Consultations (ABCs) with Kyrgyzstan in the year 2010 to strengthen engagement on a variety of financial, political business, and other matters (Coates, 2012, p.119).

The collective U.S budgeted support to Kyrgyzstan on account of 1992-2010 was worth $\$ 1.22$ billion (all organizations and agendas). Kyrgyzstan ranked third in such relieve per capita amongst descendant republics of Soviet, analytic of the government of U.S and congress approved help in the early 1990s for its obvious development in reformation and further lately to help anti-terrorism, boundary defense, and actions in Afghanistan. Though, a great deal of support for the Transit Center of Manas was not incorporated in this sum (Nichol, 1995,). The U.S gave support of 312.49\$ million for Expansion of Economy, for Fair Governance and follow the democratic norms $190.97 \$$ million; $92.54 \$$ million for Investment in people, for Civilization 264.62\$ million, $315.57 \$$ million for Safety and Harmony and for Cross-Cutting and Support for MCC Program 45.52\$ million to Kyrgyzstan (The US Department of State, 2012).

Following the revolution in Kyrgyzstan of April 2010 and in June 2010 racial aggression in the country's southern zone, U.S made commitments of about $\$ 90$ million as immediate civilization and other support besides appropriated support to foreign matter worth $\$ 53.6$ million for 2010 . Foreign support was $\$ 47.399$ million in 2012 and \$41.4 million in 2011 (Nichol, 2013). The government of Kyrgyzstan welcomed extra civilization support from the Office of Transition Initiatives (OTI) of USAID after the year 2010 government transformation. OTI supplied \$21 million to finance 415 projects that helped the Provisional Government and harmony creating endeavors in the south of Kyrgyzstan. (Marat, 2013b, p.3) limited 


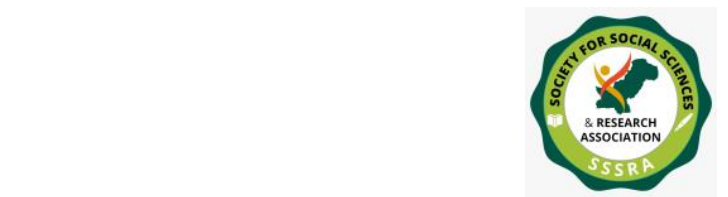

The Rise and Decline of US Interest ...

data provided for the economical relationship. Kyrgyzstan exports apparel, textiles, and pharmaceutical products to the United States. It imports merchandise, machinery, electronics, and food products from the United States. Kyrgyzstan has signed a bilateral investment treaty with the United States. The treaty on double taxation that was signed by the United States and the Soviet Union remains in effect between the United States and Kyrgyzstan. Kyrgyzstan also signed a trade and investment framework agreement with the United States and other Central Asian countries establishing a regional forum for addressing trade issues and enhancing trade and investment between the United States and Central Asia.

\section{Defense Relations}

After the events of 9/11, the Central Asian scenario changed radically and the U.S was capable to utilize its armed forces and political bindings with the states of Central Asia to bring in forward armed forces bases in this region for its battle in opposition to terrorism in Operation Enduring Freedom. The American strategy related to this region wanted to get rid of the remaining Russian imperialism in this region. The subsequent military operation in Afghanistan had presented the Central Asian regimes with an opportunity to diversify their security relations. This may lead to a new geopolitical environment in the area.

Kyrgyz President Askar Akayev has denounced the terrorist attacks. In his telegram of condolence, he said that "This tragic event in the USA demonstrates once again that terrorism has no national boundaries". (Central Asia Report, 2001, September 13) The Implication of Kyrgyzstan to the U.S was augmented following the $9 / 11$ incident and requested to use Kyrgyz airspace for military and civilized utilizations while its movement in Afghanistan to expel the regimes of Al-Qaida and Taliban was in progress. Kyrgyzstan embraced the war on terrorism and, after negotiations with the US and Russia, welcome US troops to the country as part of an international anti-terrorism force. It was also facing terrorism in southern borders.

On 5 December 2001 officials of the U.S and Kyrgyzstan approved a one-year accord related to access to bases, that allowed the United States and allied forces to utilize the airport of Manas outside of Bishkek, the capital of the country. Later on, the accord was extended for a second year, and Kyrgyzstan, on 5 June 2003 committed to an extension of three years. (Miller, 2006, p.5) Kyrgyzstan had offered a base to confront terrorism beyond a spirit of unity with the U.S, not claiming any quid for quo. Such guts were also apparent practically. A figurative 


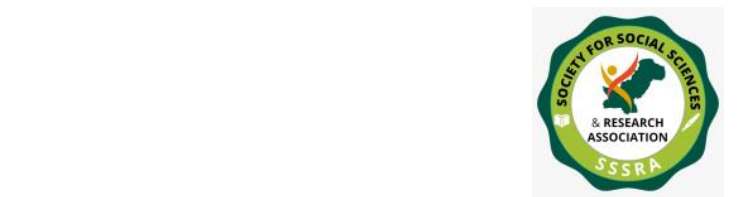

Pak. Journal of Int'L Affairs, Vol 4, Issue 1 (2021)

The Rise and Decline of US Interest ...

yearly charge of US\$2 million was the fee for the U.S to utilize the Manas airbase. (Norling \& Swanström, 2008, p.1-2.)

The Manas airbase was vital as a logistical nucleus for transferring people and for refilling processes. At the base, approximately, 1000 U.S. troops were stationed that sends airborne tankers to Afghanistan daily, in addition to the standard transfer of apparatus, food medical materials, bullets, and allied troops into Afghanistan (Cooley, 2005, p.2). Kyrgyzstan hoped to receive a meaningful boost in foreign aid and income from the landing fees, fueling, and new jobs. The domestic economic impact of the airbase had also been substantial, serving as an additional bonus for Kyrgyz support. The loss of the Uzbek base further underscores the importance of access to the Manas base, prompting a July 2005 visit by Rumsfeld to secure assurance that the U.S. military could stay in Kyrgyzstan as long as necessary (Miller, 2006, p.5).

The U.S. Department of Defense saw advantages in the base, but there was no way that the relationship could transform the country into a linchpin state for the United States in the region, given its small population, the limited potential of its economy, Kyrgyzstan's relatively isolated location, and the size and condition of the Kyrgyz military.

In the subsequent few years, this armed forces association amid the Kyrgyzstan and U.S stayed steady owing to the millions in financial support given by the U.S and worldwide groups supported by officials of America. Yet, the embassy of the U.S situated in Bishkek responded to the spirit of unity of the Kyrgyz Republic and Akayev's grant of U.S forces on its land by openly admiring the depose of him in the year 2005's Tulip Revolution. Mr. Bakiyev's newly nominated President had the intention to overturn all agendas applied by Akayev also had a depressing impact on concerns of the U.S. It did not take much time unless the government of Bakiyev in Kyrgyzstan began pushing claims to lift the rent off base. Following the prolonged concessions, the accord was accomplished in July 2006 on a raise from $\$ 2$ million annually for renting the base to $\$ 17.4$ million for five years and the U.S vowed to give several types of aids to Kyrgyz's republic totaling $\$ 150$ million. (Joint Statement, the United States and the Kyrgyz Republic on Coalition Airbase. 2006)

Talks nearly derailed in July 2006, diplomats of the U.S were charged by officials of Kyrgyzstan with doing the spy work and were pushed out of the country. 


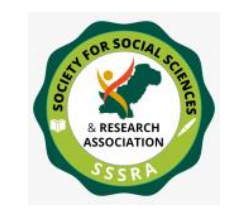

The Rise and Decline of US Interest ...

Immediate response by the U.S was witnessed in this regard and to more worsen apprehensions in December 2006 a citizen of Kyrgyzstan was murdered by a soldier of the U.S while protecting the airbase, it prompted further calls by local leaders for U.S exclusion. Officials of Washington gave no signs that the U.S had intentions to exit anytime shortly. (Cullison, 2009)

President Bakiyev, on 3 February 2009, declared while visiting Moscow that he had the intention to shut down the airbase of Manas. Several spectators hypothesized that the pronouncement was urged by Russia, which gave Bakiyev the offer of USD 300 million credits for financial growth and a USD 150 million aid to stabilize the budget in the wake of the global financial slump. The statement was given by Russia that it would mark off the majority of a $\$ 180$ million debit. (Nichol, 2013,) After conciliations, on the other hand, the Defense Department of the U.S of shared advantage had been finished with the government of Kyrgyzstan to maintain the recently renamed Transit Centre at Airport of Manas open. In the lights of the conditions of the standing of armed forces accord; 180 days were available for vacating the airbase. Annual fee payment for the employment of soil and services at the Airport of Manas was supposed to be augmented from $17.4 \$$ million to $60 \$$ million yearly and the U.S vowed other increased help. (Coates, 2012, p.119)

At first following the April 2010 dismissal of President Bakiyev, several bureaucrats in the provisional administration declared or meant that the terms of the rent would be evaluated. On 2 December 2010, Conference with Clinton, the Secretary of U.S, the fresh President of Kyrgyzstan, Mr. Roza Otunbayeva, emphasized that the Transit Centre of Manas was a major provider to the safety of the region and the that republic of Kyrgyzstan would assist its actions in any case via the year 2014, in proportion to American Government aims for departure its armed forces. (Ibid)

Almazbek Atambayev, the president of Kyrgyzstan, and the parliament had declared that the accord of basing had not given renewal when it expires in 2014. Starting from the year 2013, reports were given by the Transit Center of Manas that it hosted around 1,500 troops of U.S and refilling tankers and aircraft transportation. In addition to hosting the Transit Center of Manas, Kyrgyzstan's state also contributed as part of the Northern Distribution Network for the transfer of armed forces supplies for Afghanistan. (Zenn, 2013) 


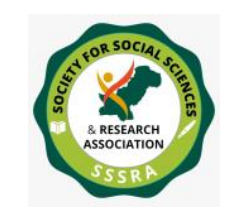

The Rise and Decline of US Interest ...

On 20 June 2013 the parliament of Kyrgyzstan collectively designated in favor of supporting the ruling of President Atambaev disapproving the accord with the U.S about the Manas Transit Center at the airport. Atambaev called to close the base by July 2014, when the treaty of that time terminated and troops of NATO were planned to depart from Afghanistan, had been steady since his election as president roughly two years ago. Atambaev intended to substitute the flair with a profitable global center. (Marat, 2013a, p.11) On 27 June 2013, He approved a bill into regulation giving the direction that the Transit Center of Manas is shut down in July 2014 upon the ending of the accord between Kyrgyzstan and the U.S regarding Transit Center which was approved in the year 2009. The U.S detached troops and apparatus from the Manas Transit Center earlier than its closing on 11 July 2014. (Kucera, 2013)

The decision of Kyrgyzstan to close the base moves Bishkek nearer to Russia. It issued the ruling days in front of Mr. Vladimir Putin, The President of Russia, unexpectedly determined to visit Bishkek to be present at a Collective Security Treaty Organization meeting. Atambaev witnessed the presence of troops of the U.S as an undermining element in the state and the pronouncement to force out the U.S troops looked to supply a political guard from another political revolution during his term. While doing the visit, Putin assured to plug in the economic breach left by the presence of U.S troops via Kant airbase of Russia. The leader of Russia repeated that it was their desire of Kyrgyzstan to request the troops of Russia to come onto its region as a reply to the rising terrorism-related hazards.

The U.S. political presence and influence likely continued in Kyrgyzstan in the foreseeable future. Yet there was doubt about the extent of U.S. military presence there. Kyrgyzstan, like its other Central Asian neighbors, was a member of the SCO, which demanded in its July 2005 meeting a clear schedule for the extraction of the American armed forces from the region of Central Asia, including Kyrgyzstan (Blank, 2005, p.8-9). Relationships between the two states get worst following the summit of SCO. The elites in Central Asia consider the March 2005 Tulip Revolution a U.S.-inspired and the U.S. engineered a coup to place a docile regime in Bishkek. As a result, the event was seen as a way to expand the influence of the United States in the area with the effect of creating suspicion in the region about the Kyrgyz government. However, following a regional trend, Bishkek had expanded its relations with China, Russia, and Iran, to Washington's dismay. The CSTO members, including Kyrgyzstan, were meant to weaken the presence of 


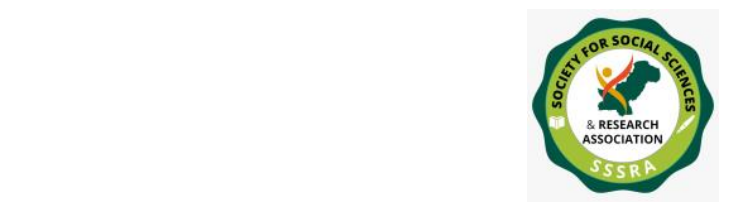

Pak. Journal of Int'L Affairs, Vol 4, Issue 1 (2021)

The Rise and Decline of US Interest ...

troops of the U.S in the Central Asian region and to remove any excuse for military actions of the U.S in this region.

As the deadline of the year 2014 for the extraction of the U.S from Afghanistan reaches, the general opinion of the U.S in the territory of Kyrgyzstan had sustained refusal. As per the elections organized by the International Republican Institute in the year 2012 , more than $60 \%$ of people had a belief that the U.S's role has been harmful to Kyrgyzstan and $42 \%$ population recognized the state as a hazard. In contrast, around $96 \%$ recognized Russia as the political ally of the country. (Marat, 2013a, p.3)

The mainly vital local impact of Manas at that time was financial, with the fitting giving the several kinds of financial gains related to base. Much like the overseas support explosion of the preceding years, base-related profits were supporting very explicit fractions of the society of Kyrgyzstan. Positively, some clear jobs were originated from the base in the area of Bishkek. After the ending of the transportation center of the U.S, the US\$ 1.7 billion national budget of Kyrgyzstan vanished at US\$ 60 million in yearly fees. The financial system all together lost another US\$ 200 million of a variety of expenditure linked with Manas. In the year 2011, the budget of Kyrgyzstan attained US\$ 150 million in link to the transportation center. (Ibid)

Bilateral military cooperation between the states inside the Partnership for Peace plan was one more significant area that visualizes combined preparation training of the Central Asian Battalion with American and other countries' armies dedicated to keeping the peace, swap of armed forces delegations, and a group of all kinds of lessons and on-the-job training. In Kyrgyzstan, defense help centered on three assignments: counterterrorism, boundary safety, and counter-narcotics. (Kucera, 2012, p.8-9) The finances were owed for building checkpoints and monitoring services at boundary passages to stop the trafficking of the drug along with giving the training and equipment.

Kyrgyzstan received military communications equipment and a variety of other systems, counting capability to view in night and helicopters as per reports. Kyrgyzstan gained benefits in the shape of armed forces medical support, NCO preparation, and Marshall Center slots. Army to Army associates was likewise increased as were visits of top rank for example Donald Rumsfeld (United States' Secretary of Defense), who went to Kyrgyzstan in Nov. 2002. In February 2002, a 


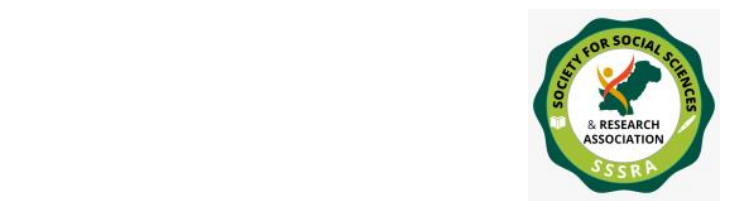

The Rise and Decline of US Interest ...

combined military exercise titled Black Knight was conducted. Troops of the United States participated in OEF and forces of Kyrgyzstan performed mountain battle and fight medicine. (Dillon, 2009) More combined exercise with Kyrgyzstan was intended through the year 2004, involving peacekeepers, Special Forces, and fast response forces. Assistance with counter-terror teaching and armed forces improvement was also assured.

\section{Findings and Conclusion}

Central Asia's geopolitical significance has become increasingly evident meanwhile there was the downfall of the Union of Soviet Socialist Republics in 1991. This region consists of the five previous Soviet States: Tajikistan, Kyrgyzstan, Turkmenistan, Uzbekistan, and Kazakhstan. This area is secluded from the world as it is landlocked on all sides. It has emerged to the attention of the United States' external strategy and established relations with Kyrgyzstan. The U.S. wanted to assist the freshly self-governing Kyrgyz republic to improve both economically and politically.

After the independence of CA, the U.S. had feared that the political vacuum would be filled by Iran and has considered Tehran a principal spot of instability in the area. The US has a limited impact on Iranians in the region of Central Asia and used Turkey as a tool. America has carved a positive role for Turkey in the newly emerged states of Central Asia, thus enhancing its prestige, power, and status among other regional powers who competed with Turkey. It has pointed to Turkey as the model of a democratic, secular state which could be emulated by CA and Turkey endorsed as a beacon of stability in the county. The USA has wanted Turkey to perform a lead character in this region because it can gain clout in the emerging region through Turkey and this attitude has enhanced Turkey's geostrategic position in the region.

The locale's criticalness to the U.S. expanded drastically after the terrorist assaults of 11 September 2001. The relationships between the United States of America and the Kyrgyz Republic have acquired a new dimension, as all four states to some degree became partners in the war against terrorism. This region has assumed a key part in America's Afghanistan system.

The main interests of the United States of America in the Central Asian states have been security, energy, and promoting democracy. It has also a significant interest in 


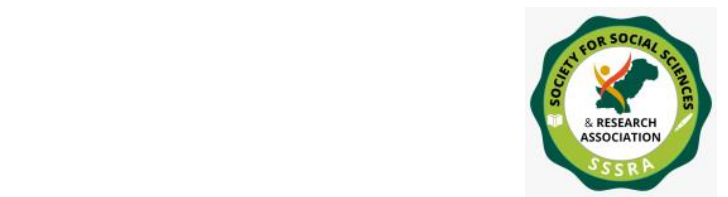

The Rise and Decline of US Interest ...

safety, encouraging steadiness, and human rights, economic and governmental reforms in the region of Central Asia.

Central Asian states have concluded agreements to allow the US and allies to establish bases to support the war on terror. Under the agreement, Kyrgyzstan has allowed the US to use the Manas base, as this unit provided a transit facility. The US used this base to carry military arsenals into the Afghan area.

The U.S. has the desire to advance solidness and democracy in the region. It's hard to conceive the acknowledgment of these objectives when Russia and China are given unconditional authority to saturate the county with their poor democratic qualifications. It is managing various clashing purposes in the area. From one viewpoint, it is attempting to give strength, however on the other; it tries to advance human rights and democracy.

America has been impatient to the point that it committed a strategy error. When U.S. has been supported the Color Revolution (the events in Andijan and the Tulip Revolution in Kyrgyzstan in 2005, sharply raised the U.S. intervention in the internal affairs of the country) to change the political framework in Central Asian nations, it advanced democratization in the district in an excessively incredible hurry. Actualities have demonstrated that the Color Revolution ideal is not appropriate for this region. The leaders of the Central Asian region had strongly repelled against political change and have successfully adopted internal political mechanisms with erratic styles to stay in supremacy. The United States' impedance in Central Asia has brought about some suspicion in Central Asian nations which thus have influenced relationships among the U.S. and Central Asian nations. Because of their suspicion of forceful American activities in this county, Central Asian nations have stated an enduring advancement in their participation with Russia and China.

This research also analysis that America has faced challenges to its interests, which are related to Central Asian internal matters that lack democracy and stability, water controlling, border and ethnic issues, energy supply, security, and terrorism. Other external factors that have created the challenges for America are Russian and Chinese political and economic strong influence and Afghan instability.

This study examines the declining American influence in Central Asia. The primary reason is the American strategies and actions inside the area; second, China and 
Russia take the U.S didn't provide any relevant data for Russia and China to interfere. as a threat and try to reduce American influence in the region; third, political unrest in Kyrgyzstan and Uzbekistan. Didn't discussed anything about Uzbekistan Yet a legitimate examination needs to recognize the numerous inadequacies of more than twenty years of US exertion in the quest for these diversions. To date, and in almost every admiration, the U.S. has neglected to attain key destinations in Central Asia. 


\section{Reference}

Aidarkul, K., \& Omarov, M. (2003). Cooperation between Russia, the US and Kyrgyzstan in New Geopolitical Context. Central Asia and the Caucasus, (19), 119-24.

Akimbekov, S. (2012). The Growing U.S. Military Involvement in Central Asia and Its Impact on U.S.-Central Asia Relations. Voices from Central Asia, (5). The George Washington University.

Blake, R. O. (2013). Press Availability Following Annual Bilateral Consultations with Kyrgyzstan. U.S. Department of State: Diplomacy in Action. https://2009-2017.state.gov/p/sca/rls/rmks/2013/203027.htm.

Blank, S. (2005). Making Sense Of The Shanghai Cooperation Organization's Astana Summit. Central Asia-Caucasus Analyst, 27.

Blank, S. (Ed.). (1998). NATO After Enlargement: New Challenges, New Missions, New Forces. Strategic Studies Institute, US Army War College.

Brletich, S. (2013). Kyrgyzstan After the Closure of Manas Transit Center. Conflict and Security. http://conflictandsecurity.co.uk/kyrgyzstan-after-the-closureof-manas-transit-center/.

Buyers, L. M. (2003). Central Asia in Focus: Political and Economic Issues. Nova Publishers.

Central Asia Report (2001, September 13). Radio Free Europe:Radio Liberty, 1 (8). https://www.rferl.org/a/1342292.html.

Coates, D. (2012). The Oxford Companion to American Politics. 2. Oxford University Press.

Cooley, A. (2005). Depoliticizing Manas: The Domestic Consequences of the U.S. Military Presence in Kyrgyzstan. Ponaras Policy Memo 362.

Cooley, A. (2006). Manas Matters: The Changing Politics of The US Military Base in Kyrgyzstan”. Barnard College, Center for Strategic and International Studies, Columbia University. 
Cooley, A. (2008). US bases and democratization in Central Asia. Orbis, 52(1), 6590.

Cullison, A. (2009). Russians Outfox US In Latest Great Game. The Wall Street Journal, 11 .

Dillon, M. (2009). Contemporary China: An Introduction. Routledge. pp. 242-243.

Kucera, J. (2012). U.S. Military Aid to Central Asia: Who Benefits? Open Society Foundations, Central Eurasia Project, Occasional Paper Series 7.

Kucera, J. (2013). Reports: U.S. Has Agreed To Leave Kyrgyzstan Air Base. Eurasia Net. https://eurasianet.org/reports-us-has-agreed-to-leavekyrgyzstan-air-base.

Kyrgyz Republic Human Rights Report. (2013). Bureau of Democracy, Human Rights and Labor, the U.S. Department State.

Marat, E. (2013a). Kyrgyzstan's Decision to Renounce Manas Transit Center Favors Russia. Central Asia-Caucasus Analyst, 15 (13).

Marat, E. (2013b). Two Decades of U.S. Kyrgyz Relations. Rethink Institute, Paper 13, The United States of America. http://www.rethinkinstitute.org/twodecades-of-u-s-kyrgyz-relations/.

Miller, E. A. (2006). To Balance or not To Balance: Alignment theory and the Commonwealth of Independent States. Ashgate Publishing, Ltd.

Nichol, J. (2013). Kyrgyzstan: Recent Developments and U.S. Interests. Congressional Research Service Report for Congress, Washington, D.C.

Nichol, J. P. (1995). Diplomacy in the former Soviet Republics. Westport, Conn. : Praeger Publishers

Norling, N. \& Swanström, N. (2008). Editor's Note: Manas Airbase and U.S. Strategy in Central Asia. The China and Eurasia Forum. 6 (4), 1-2. http://www.asiastudies.com/asia/SilkRoad/CEF/200812/ednote08manas.pdf. 
Office of the Historian. (n.d.). A Guide to the United States' History of Recognition, Diplomatic, and Consular Relations, By Country, Since 1776: Kyrgyzstan. Office of the Historian Bureau of Public Affairs, United States Department of State. http://history.state.gov/countries/kyrgyzstan.

Olcott, M. B. (2010). Central Asia's Second Chance. New York: Brookings Institution Press.

Peimani, H. (2009). Conflict and security in Central Asia and the Caucasus. AbcClio.

Puddington, A. (2013). Freedom in the world 2013: Democratic Breakthroughs in the Balance. Washington, DC: Freedom House.

Roy, A. N.(2010). Kyrgyzstan: A Pawn in the Geopolitical Game. Mainstream, XLVIII (37).

Savina, L. (2014, September 29). Kyrgyz-American Economic Forum held in Bishkek. International Business Council. http://www.ibc.kg/en/news/ibc/535_kyrgyzamerican_economic_forum_held _in_bishkek

Spratlen, P. (2011). Statement on Celebrating 20 Years of Friendship and Cooperation between the Kyrgyz Republic and the United States. DIPNOTE, U.S. Department of State, Offical Blog. http://2007-2017blogs.state.gov/stories/2011/12/30/celebrating-20-years-friendship-andcooperation-between-kyrgyz-republic-and.html

The U.S. Deparmtent State (2012) Kyrgyz Republic. The U.S. Deparmtent State Office of the Coordinator of U.S. Assistance to Europe and Eurasia, Foreign Operations Assistance Fact Sheet in Action, https://20092017.state.gov/p/eur/rls/fs/193603.htm.

The White House. (2011, October 31). Statement by the President Obama on the Presidential Elections in Kyrgyzstan. http://www.whitehouse.gov/the-pressoffice/2011/10/31/statement-president-presidential-elections-kyrgyzstan. 
Todd, B. (2011). Kyrgyzstan: Renewed US Pressures. Mainstream, XLIX (9).

Trade in Goods with Kyrgyzstan. (2020). Foregin Trade: U.S. Census Bureau. https://www.census.gov/foreign-trade/balance/c4635.html.

U S Government Publishing Office. (2020) Public Papers of the Presidents of the United States: Administration of George W. Bush. (Book I-January 1 To June 30, 2005). https://www.govinfo.gov/content/pkg/PPP-2005book1/pdf/PPP-2005-book1.pdf.

U.S. Embassy of Bishkek. (2006). Joint Statement the United States and the Kyrgyz Republic on Coalition Airbase. U.S. Embassy. http://bishkek.usembassy.gov/july_14_joint_statement_on_coalition_airbas e.html,

U.S. Relations with Kyrgyzstan. (2021, January 2). Bilateral Relations Fact Sheet, Bureau of South and Central Asian Affairs. https://www.state.gov/u-srelations-with-kyrgyzstan/

USA International Business Publications (2012). Kyrgyzstan Business Law Handbook Vol-1: Strategic Information and Basic Laws. International Business Publications USA.

White House Press Release (2002, July 30). Visit by President Akayev of the Kyrgyz Republic to Washington. Office of the Press Secretary, U.S. Department of State https://www.hsdl.org/?abstract\&did=447293.

Zenn, J. (2013). What Options For U.S. Influence In Central Asia After Manas? Central Asia-Caucasus Analyst, 15, (05). 6-7. 